\title{
Beyond the Treasury of San Isidoro: A Tale of Two Projects
}

\author{
Therese Martin
}

\begin{abstract}
In this methodological essay, I present the fruits of research carried out by an interdisciplinary group of scholars 2016-2018, which centered on the Treasury of San Isidoro de León, while also introducing the more wide-ranging comparative work going forward 2019-2022 under the auspices of a reconfigured team. By republishing our studies in open access, we aim to reach a larger community of scholars; our longer-term goal is to move further out into the consciousness of modern society, locating for an interested general public the Leonese collection within its broader historical framework and holding it up for comparison with other significant sites. Cross-cultural luxury objects oblige a shift in the direction of our historical gaze, bringing into clear focus the many collaborations across faiths and the repeated examples of protagonism by women during the central Middle Ages.
\end{abstract}

\section{Keywords}

crosscultural objects - Iberia - interdisciplinary research - ivory - metalwork - silver textiles - women

Nine-hundred and fifty-five years after the presumed founding in 1063 of the treasury of San Isidoro de León, the year 2018 saw the completion of a collaborative research project centering on the Leonese collection. At that time, it was clear that our research was leading to rich and unexpected results which merited further investigation, and so I sought more ambitious funding to exploit the remarkable developments arising from the initial grant. We were fortunate in 2019 to receive the generous support of a Spanish National Research Challenge Grant, allowing the fifteen members of the reconfigured team, drawn together from six countries, to strike out in exciting new directions 
through the end of 2022. ${ }^{1}$ In the present methodological essay, I reflect on themes and ideas that have emerged since the key results of the first project were submitted for publication two years ago, identifying in this chapter the significant additions to the bibliography that have appeared in the meantime. I also lay out a blueprint for the team's research in the coming years. In addition to expanding the scope of our investigations, the new grant has also made possible the publication of this book in open access: here, gathered in one volume, are the set of studies resulting from the initial Treasury project, completed now by cross-referenced images, a composite bibliography, and a tripartite index to facilitate an understanding of the interconnected nature of the different topics under analysis. ${ }^{2}$ By republishing these studies in open access, we aim to bring our work to the attention of as broad a global readership as possible, offering a new view into the roles played by prior research in our current project.

Following the present essay, the volume continues with my chapter, "Caskets of Silver and Ivory from Diverse Parts of the World: Strategic Collecting for an Iberian Treasury," which presents San Isidoro's treasury and analyzes the complexities involved in researching this collection during its heyday from the late eleventh century through the first half of the twelfth. This chapter also takes a deep dive into a later moment in the long life of the monument, which was brought to light during our carbon-14 testing of an object from San Isidoro known as the Beatitudes Casket (Figure 1.1; now held by the Museo

1 This second Treasury project (2019-2022) is funded by The Medieval Iberian Treasury in Context: Collections, Connections, and Representations on the Peninsula and Beyond (National Research Challenge Grant, Spanish Ministry of Science, Innovation, and Universities, AEI/FEDER, RTI2018-o98615-B-Ioo, PI Therese Martin). For the publication of the present volume, additional support has generously been provided by The Index of Medieval Art, Princeton University, and the College of Liberal Arts of The University of Mississippi. (Previous funding and acknowledgments are noted by each author in her respective chapter.) I am very grateful to all team members who contributed to both Treasury projects, and especially to Amanda Dotseth, Jitske Jasperse, and Ana Rodríguez, whose incisive critiques of an earlier draft greatly improved the final version of this essay.

2 Chapters 2-8 initially appeared as a special double issue of Medieval Encounters 25/1-2 (2019), having originated in conference presentations at Princeton University in May 2017 (see Chpt. 2, n.1, for further details, including a complete list of speakers). Chapter 9 was originally published as Nancy L. Wicker, "The Scandinavian Container at San Isidoro, León, in the Context of Viking Art and Society," Journal of Medieval Iberian Studies 11/2 (2019): 135-156; it is here reprinted by permission of the publisher Taylor \& Francis Ltd, http://www.tandfonline. com. Wicker's article was developed from a presentation given at Jornadas Proyecto Tesoro. Resultados de la investigación interdisciplinar sobre el tesoro de San Isidoro de León, held in September 2018 at San Isidoro itself. The authors are grateful to Medieval Encounters and to the Journal of Medieval Iberian Studies for facilitating the republication of our work in this revised and expanded format. 
Arqueológico Nacional in Madrid, no. 52092), whose meaning was further clarified by a fourteenth-century document from San Isidoro's archive. Digging extensively into the context of other written sources, Ana Rodríguez, in Chapter 3 , "Narrating the Treasury: What Medieval Iberian Chronicles Choose to Recount about Luxury Objects," investigates the ways in which a rare few objects were featured in chronicles of the twelfth and thirteenth centuries. Surprisingly, she finds that Iberian chroniclers tended to ignore the magnificent works they saw all around them, save for select pieces that were singled out in the narratives and highlighted especially for their exotic materials or prestigious provenance.

Turning next to textiles, two scholars who have been working closely together unfold the diverse silk holdings at San Isidoro to tease out the multiple meanings that have accrued to them. Ana Cabrera Lafuente takes an archaeological approach in Chapter 4, "Textiles from the Museum of San Isidoro (León): New Evidence for Re-Evaluating Their Chronology and Provenance." She compiles the first in-depth, analytical catalogue of the textile fragments (see Chpt. 4, Table 4.1), placing each piece in relation to silks held by ecclesiastical or civic

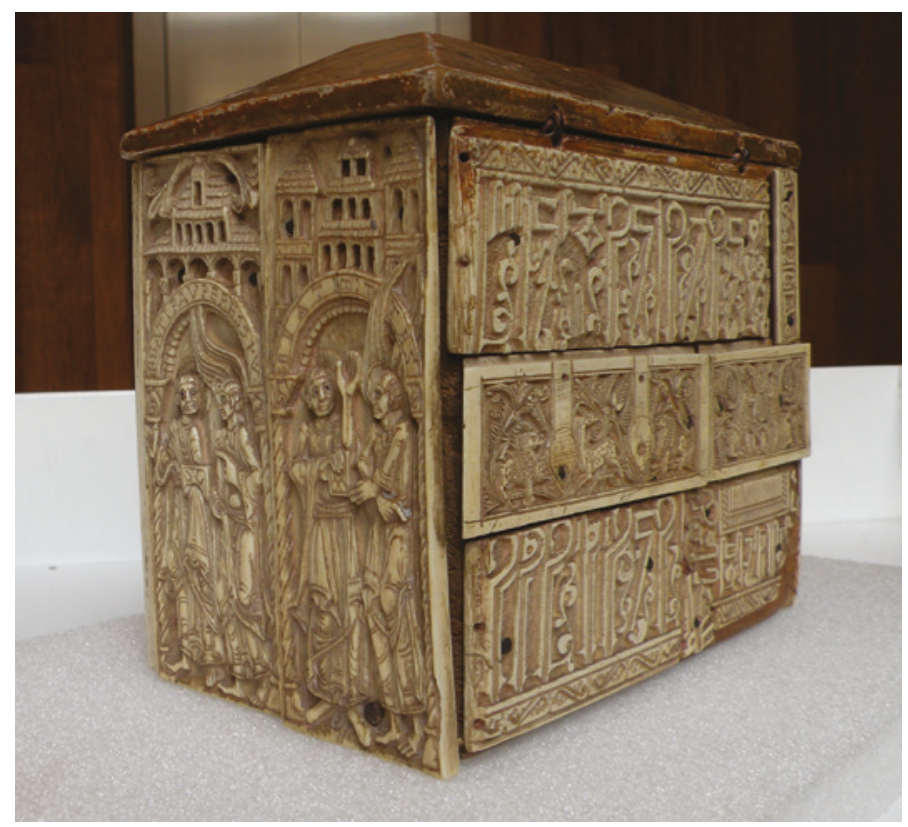

FIGURE 1.1 Beatitudes Casket, oblique view, ivories from the late eleventh century (?) on fourteenth-century wooden box (Madrid, Museo Arqueológico Nacional, Inv. No. 52092). See also Figs. 2.6-2.8. PHOTO: THERESE MARTIN 
museums around the world. Her study breaks ground through the application of technical analysis, including radiocarbon dating that reveals unexpectedly early chronologies for several silks in the Isidoran collection. Placing these textiles in their historical context(s), in Chapter 5 by María Judith Feliciano, "Sovereign, Saint, and City: Honor and Reuse of Textiles in the Treasury of San Isidoro (León)," the author follows the movements of textiles into and around the Iberian Peninsula, showing that both they and the treasury were parts of a living process. She draws attention to the freighted symbolic nature of royal drapings and holy textile relics, essential to the construct of León as a capital city in both medieval and early modern moments. Meaningful locations are also crucial to the singular artifact studied by Jitske Jasperse in Chapter 6, "Between León and the Levant: The Infanta Sancha's Altar as Material Evidence for Medieval History." Her detailed investigation of the remarkable inscription and unusual material of a portable altar in the treasury of San Isidoro brings to light hitherto unrecognized networks and connections through kinship, gender, and imaginary pilgrimage, both in the twelfth century when the altar was created and in the life the object would take on in the centuries to come.

In the following chapters, research perspectives broaden out from treasured objects to consider their settings and audience in medieval León. Pamela Patton, in Chapter 7, "Demons and Diversity in León," brings to the fore the layered meanings of a hagiographic image in the Romanesque frescoes of the so-called Pantheon of the Kings. ${ }^{3}$ In an extraordinary scene, Saint Martin is tempted by a richly dressed individual who is identified by inscription as the devil; by contrast with the textual source on which the representation is based, the author reads this devil's painted garb at San Isidoro as designed to evoke the exquisite țirāz textiles of the Islamicate world. Chapter 8 by Julie Harris, "Jews, Real and Imagined, at San Isidoro and Beyond," investigates the presence of Jews in the city of León, calling to our attention the surprisingly few Old Testament relics at San Isidoro, by contrast with parallel holdings at the royal and ecclesiastical centers of Oviedo and Toledo. In León, it is not at San Isidoro but instead at the Cathedral where the author finds clear traces of royal interactions with the city's now dispersed Jewish community. Finally, the volume closes with Chapter 9 by Nancy Wicker, "The Scandinavian Container at San Isidoro, León, in the Context of Viking Art and Society," which centers on a tiny and unique object, the only Viking-style artifact to have been preserved in the entire Iberian Peninsula. Addressing the diminutive container's decoration and function, the author points out the work's hybrid

3 In April 2020, Pamela Patton's study was awarded the Charles Julian Bishko Memorial Prize for best article on Spanish medieval history by the Association for Spanish and Portuguese Historical Studies. 
character, which marries a design from the far north with a proposed usage typical of Islamic societies, before the box's eventual conversion into a reliquary. That a Scandinavian container forms part of the treasury of San Isidoro is no accident, as a reading of all the chapters in this volume makes clear, reaffirming the polysemic character of this extraordinary multicultural collection.

As this brief review of the chapters in the present book sums up, the impetus that inspired the initial Treasury project sprang from the remarkable range of objects once gathered at a single Iberian monument-San Isidoro de León-revealing multiple transcultural networks for the central Middle Ages. ${ }^{4}$ The works in this treasury only rarely appear in studies beyond those focused on Spanish medieval art history, despite the broad relevance of the assemblage as a whole for scholarship today. In this second, more wide-reaching iteration of the Treasury project, art historians, archaeologists, curators, and historians pursue a common goal across two major lines of inquiry: the geographically charged nature of objects, and women as vectors of cultural exchange. Thanks to the generosity of this second grant, the tenth- to twelfth-century holdings at San Isidoro are now functioning as a test case from which our attention turns outward to comparative study. The team's collaborative investigation of how and why medieval objects crossed cultural, religious, and political bordersoften by the hand of a woman - addresses two challenges faced by modernday society. First, transcultural objects make manifest the connections all too often missing from official written history; ${ }^{5}$ they are tangible demonstrations of what would otherwise remain unremarked. This is especially important

4 Our thanks are offered especially to the staff of the Museo de la Real Colegiata de San Isidoro de León under the direction of Luis García Gutiérrez and Raquel Jaén, and to the Museo Arqueológico Nacional in Madrid, particularly to Sergio Vidal, head of the medieval department, along with Isabel Arias and Beatriz Campderá Gutiérrez. Both institutions generously facilitated first-hand access, allowing team members to examine and photograph the objects and to carry out technical analyses over the course of multiple campaigns, without which the first Treasury project would have been impossible. I am also grateful to the Cooper Hewitt Smithsonian Design Museum, Glencairn Museum, Metropolitan Museum of Art, Museo de la Catedral de Astorga, Museo de la Catedral de León, Museo de la Catedral de Santiago de Compostela, Museo de León, Museo Tesoro de la Catedral Primada de Toledo, National Gallery of Art (Washington, D.C.), and the Trésor de la Catedral de Girona.

5 An example of this can be seen in the so-called Historia Silense, for which a critical edition has been published at long last. In this chronicle, likely written in León during the first quarter of the twelfth century, interactions between Muslims and Christians are portrayed as unremittingly fraught. See Juan A Estévez Sola, ed., Historia Silensis, in Chronica Hispana saeculi XII, Pars III. Corpus Christianorum Continuatio Mediaevalis ${ }_{71} \mathrm{~B}$ (Turnhout: Brepols, 2018). See also the studies in Historia legionensis (llamada silensis). Écriture de l'histoire, ed. Georges Martin, special issue, $e$-Spania 14 (2012), https://journals.openedition.org/e-spania/ 21568 (consulted 14 April 2020). 
for recognizing the multiple layers of meanings that build up through contacts across and among religious groups, sometimes bellicose but not as determinedly so as the normative literature of the Middle Ages would have its readers believe. Second, this project highlights some of the many moments in which medieval women played a leading role in the movement of objects from distant lands. Female protagonism, indisputably evident in León-Castilla during the central Middle Ages, serves in our research as a touchstone for other medieval treasuries to determine whether the case of San Isidoro, as argued in the present volume, represents an exception or an as-yet unrecognized rule.

The results of the first Treasury project demonstrated that the creation of a medieval treasury offers a material witness through which the interests and aspirations of those who established it are revealed. Although some of the works from the Isidoran treasury had previously received sustained scholarly attention, especially by Ángela Franco, ${ }^{6}$ other pieces were all but unknown outside Spain, and none had ever been subjected to scientific analysis such as carbon-14 dating. ${ }^{7}$ For San Isidoro, a critical re-reading of the material and written evidence reveals generations of royal ambitions, first those evident in the treasury's storied foundation by Fernando (r. 1037-1065) and Sancha (d. 1067), and later through its restoration in the twelfth century by their descendants, who were clearly conscious of their lineage. The paucity of objects post-dating the middle of the twelfth century which can be associated with the Leonese treasury suggests that the royal practice of offering precious belongings to their dynastic monastery waned throughout that century, with the Limoges-style enamelwork reliquary marking an end to the era of large-scale royal sponsorship (Figure 1.2). ${ }^{8}$ The Treasury project is now looking more deeply into these developments, examining the periodic bursts of donation activities by rulers. If radiocarbon dating pushed our investigation further during the first grant, it was archival research which uncovered the nexus that was

6 From her seminal work of 1991 to her monograph in 2012, among the publications by Ángela Franco Mata that address the Leonese treasury are: "El tesoro de San Isidoro y la monarquía leonesa," Boletín del Museo Arqueológico Nacional 9/1 (1991): 35-68; "La eboraria de los reinos hispánicos durante los siglos XI y XII," Codex Aquilarensis 13 (1998): 143-166; “Liturgia hispánica y marfiles: talleres de León y San Millán de la Cogolla en el siglo XI," Codex Aquilarensis 22 (2006): 92-145; "Tesoros de Oviedo y León. Problemas estilísticos, liturgia e iconografía," Boletín del Museo Arqueológico Nacional 27-28 (2009-2010): 51-118; Arte leonés fuera de León (ss. IV-XVI) (León: Edilesa, 2012).

7 For the results of the radiocarbon analysis, see Chpts. 2 and 4 in the present volume.

8 This object would benefit enormously from metals testing, which we hope to carry out in the coming years, to determine if the apparently late twelfth-century Limoges style of the enameled copper (?) casket can reliably be tied to a particular time and place of production. In her 2013 dissertation, Melanie Hanan contextualized this type of shrine within the larger international genre; see her "Romanesque Casket Reliquaries: Forms, Meaning, and Development," PhD diss., Institute of Fine Arts, New York University, 2013, esp. 201-222. 


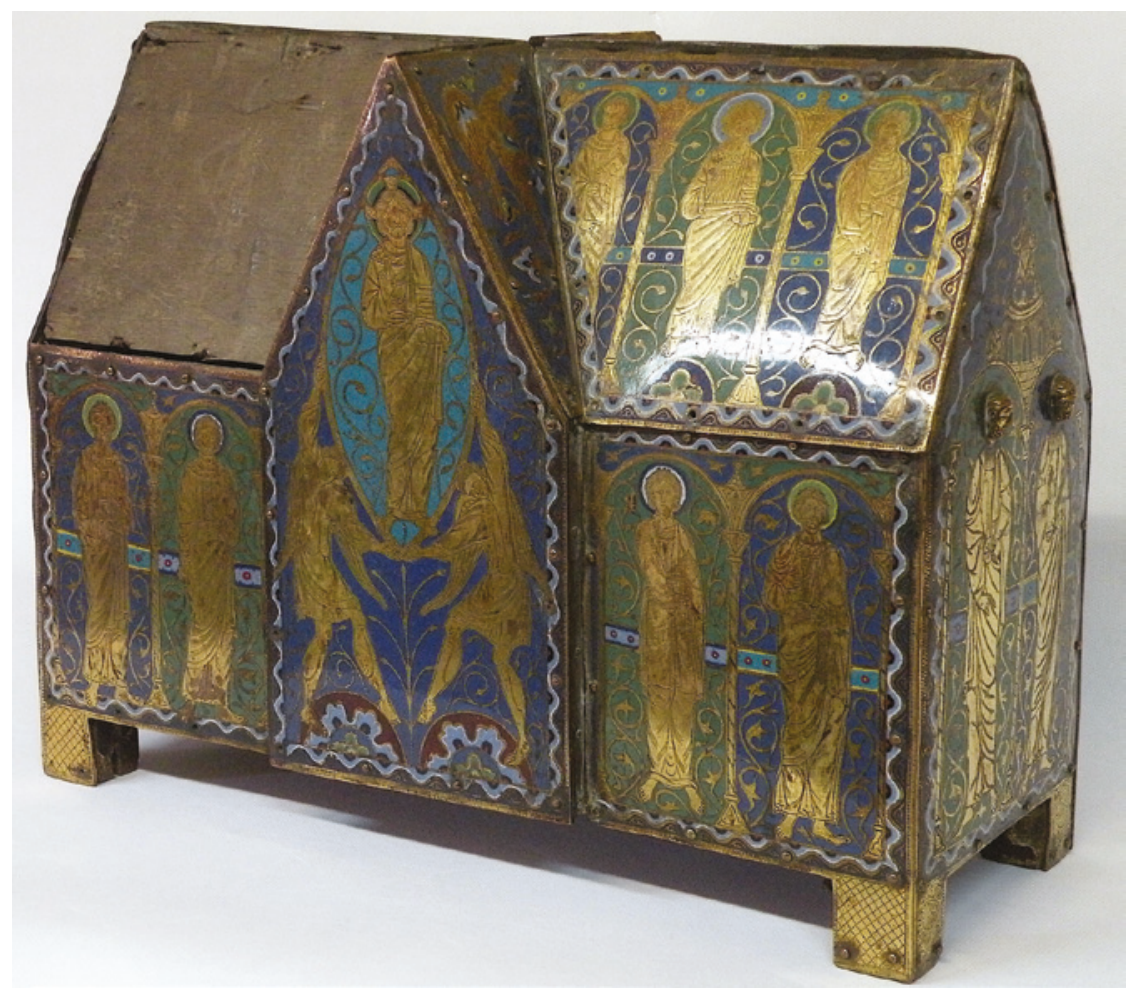

FIGURE 1.2 Limoges-style enamelwork casket, late twelfth century (?) (Museo de la Real Colegiata de San Isidoro de León, Inv. No. IIC-3-089-002-00o3). See also Fig. 5·5. PHOTO: THERESE MARTIN

key to the history of the ecclesiastical — rather than the royal—institution of San Isidoro. As detailed in Chapter 2, the fourteenth century was revealed to be a time of reaching out to non-elite donors, men and women who were encouraged to join the confraternity with an eye to benefitting in the hereafter.

Moving outward from León, the Treasury project seeks to offer a way into the meaningful re-use and repurposing of luxury goods, both within and across cultures during the central Middle Ages, together with the representation of precious items for medieval and modern audiences. At the heart of both phases of our research are the multidisciplinary challenges involved in studying works disparate in material, mode, and moment of manufacture, which were once gathered together at individual medieval treasuries. Team members delve into the meanings behind the presence of artifacts from other cultures, reconsidering the paths by which prized possessions arrived at their destinations, with commerce, plunder, marriage, and modern nationalistic expropriation among them. In the coming years, we will continue to explore the question of how medieval treasuries accommodate the evolving interests of their owners across 
the centuries. ${ }^{9}$ Throughout this research project, objects ever serve as evidence alongside - and sometimes in opposition to-archival sources. Additional radiocarbon dating of textiles and objects, whether from the Leonese treasury or other sites, will provide comparative data for the scientific testing done during the first project. Technical analyses, including dyes characterization of textiles, non-invasive X-ray fluorescence for metals, and carbon-14 for organic materials, make crucial contributions to the larger story that objects can tell about manufacture, techniques, and places of origin. ${ }^{10}$

In the present phase of the Treasury project, issues of audience come more fully into focus as a dual concern for facets medieval and contemporary: ${ }^{11}$ we now bring to bear the place of museums in determining our understanding of medieval "artworks," items that are thus deemed worthy of collecting. This project takes as a given that the material reality of treasuries-ivories, metalworks, precious stones, and silks - can best be comprehended if the objects are analyzed within their complete settings, as well as in tandem with textual and visual representations. As we shift our gaze outward beyond the Leonese treasury, we ask how this collection compares to assemblages in other spaces, from a Swiss monastery, to courts in the easterly reaches of twelfth-century Europe, to the Mediterranean kingdom of Sicily. As at San Isidoro, a defining characteristic of these regions is that they represent crossroads of intense cultural interchange, conjuring rich comparisons with Iberia during the central Middle Ages. Capital cities like León and Palermo hold a place of honor at the center of our research because they manifest the links that were forged between far distant lands-across religious boundaries and through the

9 On the relics and reliquaries, for example, now in the treasury of the Cathedral of Oviedo-a site with important precedents and parallels to San Isidoro-see the research of Raquel Alonso Álvarez, including her latest article, "Royal Power and the Episcopacy: Eleventh- and Twelfth-Century Relics from Oviedo Cathedral," in Ideology in the Middle Ages: Approaches from Southwestern Europe, ed. Flocel Sabaté (Leeds: Arc Humanities Press, 2019), 203-234. See also the important study of the Oviedan objects' inscriptions in Arabic (not pseudo-Kufic, as previously presumed) by María Antonia Martínez Núñez, "Inscripciones árabes en la Catedral de Oviedo: El Arca Santa, la Arqueta del Obispo Arias y la Arqueta de Santa Eulalia," Territorio, Sociedad y Poder 11 (2016): 23-62.

10 For in-depth and multifaceted analyses approaching a single object from multiple perspectives and disciplines, see Klaus Gereon Beuckers and Dorothee Kemper, eds., Das Welandus-Reliquiar im Louvre. Ein Hauptwerk niedersächsischer Emailkunst in interdisziplinärer Perspektive. Objekte und Eliten in Hildesheim 1130 bis 1250 (Regensburg: Schnell \& Steiner, 2018).

11 On the display of exotic objects and the astonished gaze of viewers, see David Ganz, "Der staunende Blick auf der Schatzkunst," in Staunen als Grenzphänomen, ed. Nicola Gess, Mireille Schnyder, Hugues Marchal, and Johannes Bartuschat (Berlin: Reimer, 2017), 247-266. 
actions of women - by the objects today in medieval treasuries and modern museums. ${ }^{12}$ This project further addresses the challenge of bringing research on underrepresented contacts into the larger scholarly consciousness. ${ }^{13}$ Such a range of geographies demands rigorous analysis and close collaboration by specialists from various fields of study. At the commencement of the original Treasury project, an international and multidisciplinary group of scholars worked closely together, while others joined in as external collaborators; each brought expertise from diverse areas of specialization. For the current phase of research, continuing members are joined by specialists with complementary areas of knowledge. In the following schema, the remits of all scholars are detailed according to their areas of expertise, together with the questions we seek to answer as a team.

As Principal Investigator, my efforts are focused on directing the various research trajectories, ensuring that all strands are interwoven so that they reinforce the fabric of the project as a whole. At the same time, I am carrying out individual work on the display of rulership, especially the luxury objects linked to reigning women in Iberia during the tenth to twelfth centuries. ${ }^{14}$ These inn clude works owned by Ermesinda of Carcassonne, countess of Barcelona,

12 See recently Umberto Bongianino, "The King, His Chapel, His Church: Boundaries and Hybridity in the Religious Visual Culture of the Norman Kingdom," Journal of Transcultural Medieval Studies 4 (2017): 3-50; Fernando Arias Guillén and Pascual Martínez Sopena, eds., Los espacios del rey. Poder y territorio en las monarquías hispánicas (siglos XII-XIV) (Bilbao: Universidad del País Vasco, 2018), especially Alberto Navarro Baena, "La memoria regia a través de los obituarios leoneses," 397-418, and Carlos Manuel Reglero de la Fuente, "El Infantado monástico: del espacio a la memoria," 419-436.

13 Recent examples include Rosa Maria Bacile and John McNeill, eds., Romanesque and the Mediterranean: Points of Contact across the Latin, Greek and Islamic Worlds c. 1000 to c. 1250 (London: Maney Publishing, 2015); Talia Zajac, "Remembrance and Erasure of Objects Belonging to Rus' Princesses in Medieval Western Sources: The Cases of Anastasia Iaroslavna's 'Saber of Charlemagne' and Anna Iaroslavna's Red Gem," in Moving Women, Moving Objects, 500-1500, ed. Tracy Hamilton and Maria Proctor-Tiffany (Leiden: Brill, 2019), 33-58. The "red gem" of Zajac's title is the same storied "carbuncle" that figures in Chpt. 3 of the present volume by Ana Rodríguez.

14 This was the subject of my 2019-2020 Samuel H. Kress Senior Fellowship at the Center for Advanced Study in the Visual Arts, National Gallery of Art. My thinking has benefitted from conversations with CASvA colleagues, as well as with specialists from area museums and universities with whom I was fortunate to meet during my stay in Washington, D.C.: Sheila ffolliott, Katherine Hansen, Genevra Kornbluth, Andrea Pearson, Christine Sciacca, and especially Laura Morreale. Aspects of this research were presented in February 2020 at CASVA and in a Dorothy Ford Wiley Lecture for the UNC Program in Medieval and Early Modern Studies, University of North Carolina, Chapel Hill. I am grateful to UNC's Jessica Boon, her students, and colleagues for their enthusiastic discussions of my research. 


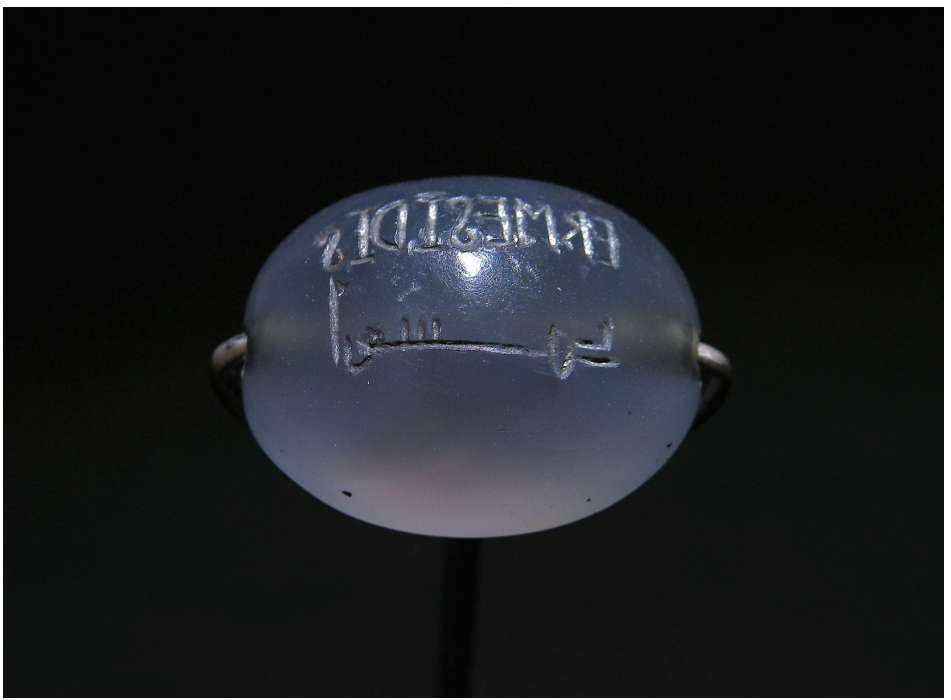

FIGURE 1.3 Seal of Ermesinda of Carcassonne, Countess of Barcelona (d. 1058), chalcedony, 3.2 X $2.0 \mathrm{~cm}$. (Trésor de la Catedral de Girona). PHOTO: THERESE MARTIN

whose lo ng rule began in 991 when she married Count Ramón Borrell (r. 972-1017); her six decades of exercising real authority encompassed all of her son's reign and half of her grandson's, only coming to an end when her grandson finally forced her from power the year before she died. Her rock crystal chess set (eschacos christalinos), possibly manufactured in Fatimid Egypt, ${ }^{15}$ is among the precious possessions known only from a codicil to Ermesinda's testament, which was written shortly before her death in 1058 at more than eighty years of age. ${ }^{16}$ However, the countess' bilingual seal survives, bearing her name in Latin and Arabic_ERMESĪDIs/_ارمسند-inscribed in reverse on a small oval stone of palest blue chalcedony (Figure 1.3). This tiny but telling

15 During the first Treasury project, Jeremy Johns and Elise Morero contributed deep learning about rock crystal, sardonyx, and other worked stone-along with lively good fellowship-during research trips to Madrid, León, and Astorga. They have underway a complete corpus of Fatimid rock crystals, from which their most recent publication is drawn. See Elise Morero, Jeremy Johns, Hara Procopiou, Roberto Vargiolu, and Hassan Zahouani, "Relief Carving on Medieval Islamic Glass and Rock Crystal Vessels: A Comparative Approach to Techniques of Manufacture," in Seeking Transparency: Rock Crystals Across the Medieval Mediterranean, ed. Cynthia Hahn and Avinoam Shalem (Berlin: Gebr. Mann Verlag, 2020), 51-66.

16 A well-known character from Catalan history, Ermesinda and her 192 charters are the subject of a doctoral thesis by Xavier Gil i Roman, "Diplomatario de Ermesèn, condesa de 
indicator of authority can still be seen in the treasury of the Cathedral of Girona, the favored site on which Ermesinda bestowed much of the great wealth accumulated during her long lifetime in power. ${ }^{17}$ Through works like Ermesinn da's seal, I investigate the ways in which material culture evoking other lands was made to buttress the authority of Iberian rulers.

All members of the team approach objects and collections through their multiple contexts: origin of materials; manufacture of artifacts; manipulations by medieval and modern owners; progression to current holder. Among the treasuries that feature in the present phase of research is that of the monastery of St.-Maurice d'Agaune (Switzerland), which has been the focus of Pierre Alain Mariaux's study for more than a decade. ${ }^{18}$ For the Treasury project, Marii aux brings comparative analysis to bear, especially relevant for the abbey's silver bejeweled Grande Châsse (Figure 1.4). Now undergoing extensive restof ration, the patron saint's reliquary is being studied while still on display to the public, offering extraordinary access to the casket's construction, down to its inner wooden core, ${ }^{19}$ and providing answers to questions in parallel to the silt ver reliquary of Saint Isidore that holds pride of place in the Leonese treasury (Figure 1.5a, b).

Three scholars with expertise in the archaeology and art history of Christian- and Islamic-manufactured textiles-a centerpiece of medieval treasuries - who collaborated closely during the first phase of the Treasury project, will continue with expanded remits in the second. Ana Cabrera Lafuente and María Judith Feliciano are investigating luxury silks from the early and central Middle Ages in such holdings as the monastery of Sant Joan de les Abadesses and the Cathedrals of Roda de Isábena, ${ }^{20}$ Santiago de

Barcelona, Girona y Osona (c. 991-1 de marzo de 1058)," PhD diss., Universitat Autònoma de Barcelona, 2004. For a recent study with extensive prior bibliography, see Jeffrey A. Bowman, "Countesses in Court: Elite Women, Creativity, and Power in Northern Iberia, 900-1200," Journal of Medieval Iberian Studies 6/1 (2014): 54-70.

17 I am deeply indebted to Joan Piña Pedemonte, director of the Trésor de la Catedral de Girona, for allowing me to study and photograph this object in July 2019.

18 Pierre Alain Mariaux, ed., L'Abbaye de Saint-Maurice d'Agaune 515-2015, vol. 2, Le Trésor (Gollion: Infolio Éditions, 2015).

19 For the work underway on the Grande Châsse, see especially Pierre Alain Mariaux, Romain Jeanneret, and Denise Witschard, "L'Économie patrimoniale comme mise en oeuvre matérielle et sémantique au sein de l'atelier médiéval: Le cas des remplois de la Grande Châsse de Saint Maurice," a paper presented at "Atelier(s) d'artiste(s). Lieux et processus de production. Matériaux pauvres-Matériaux nobles," held at the MuCEM, Marseille in October 2018. Published online: http://www.opusagaunum.ch/category/article/ (consulted 14 April 2020).

20 Ana Cabrera Lafuente, María Judith Feliciano, and Enrique Parra, "Medieval Iberian Relics and Their Woven Vessels: The Case of San Ramón del Monte († 1126), Roda de 


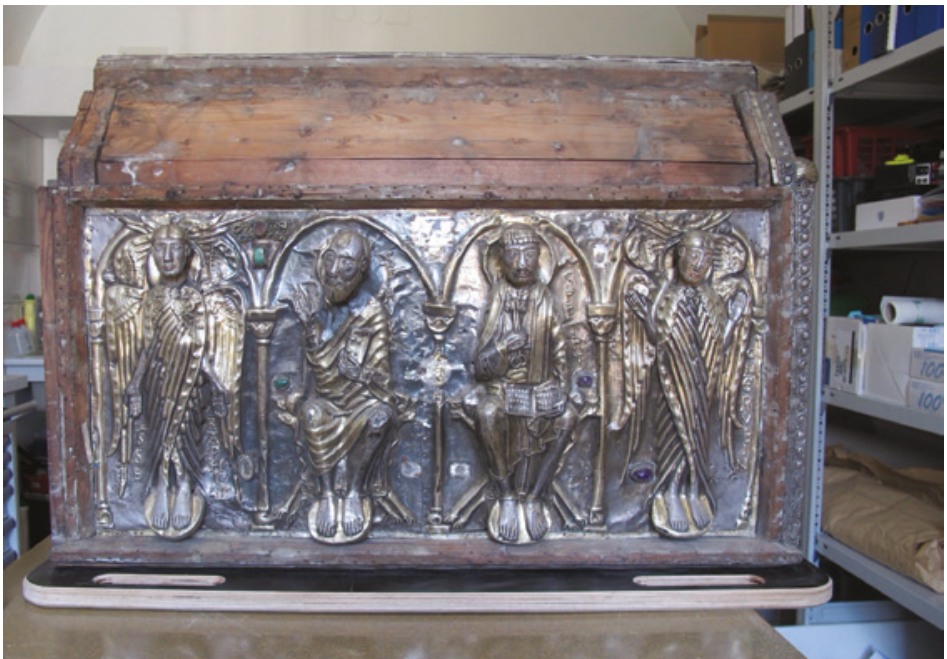

FIGURE 1.4 Grande Châsse, restoration underway, Monastery of St.-Maurice d'Agaune (Switzerland).

PHOTO: PIERRE ALAIN MARIAUX
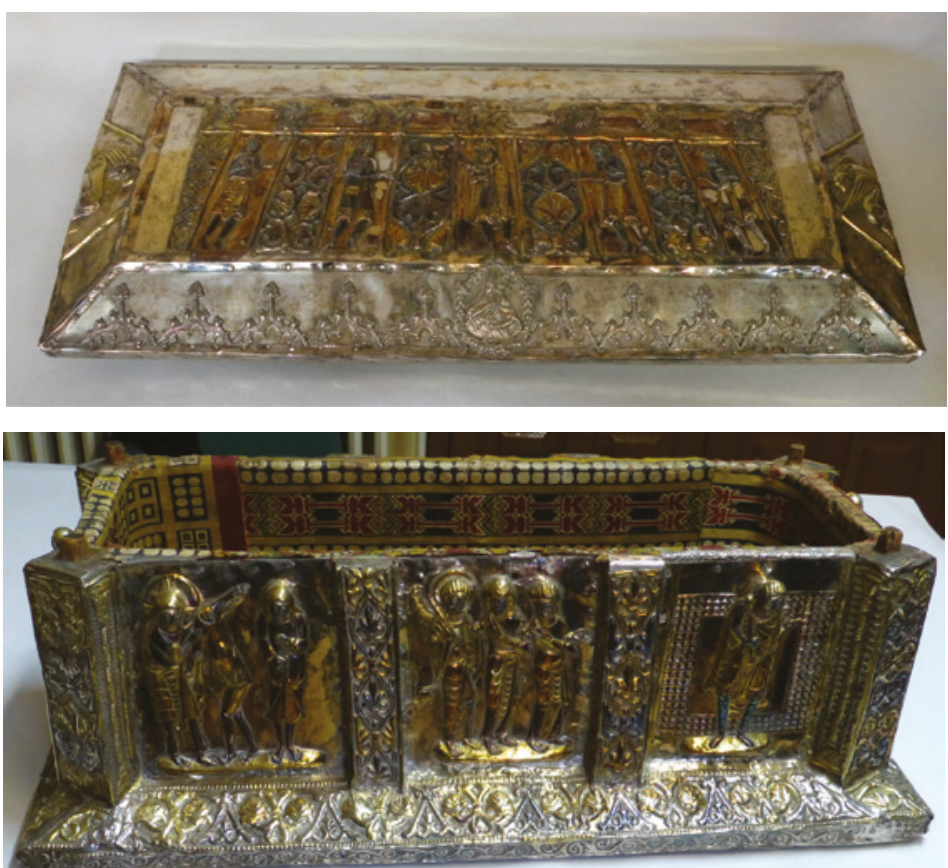

FIGURES 1.5A, в Lid and reliquary casket of Saint Isidore, silver and wood, 1063? (Museo de la Real Colegiata de San Isidoro de León, Inv. No. IIC-3-089-002-0001). See also Figs. 4.7, 5.1, 5.2.

PHOTOS: A, THERESE MARTIN; B, AMANDA DOTSETH 

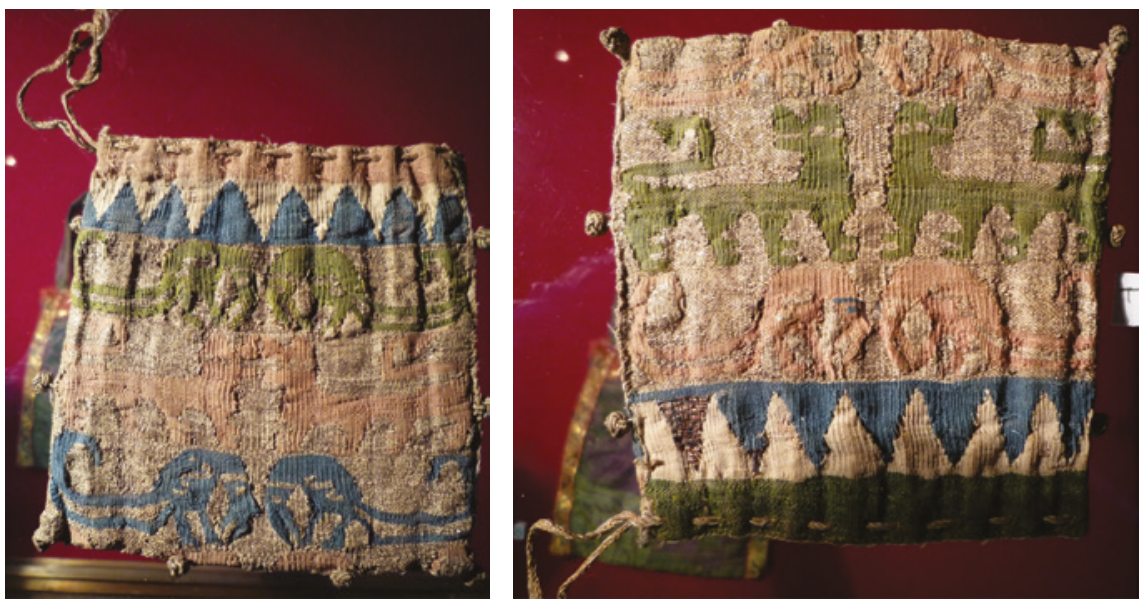

FIGURES 1.6A, B Relic bag in tapestry weave, with leonine creatures, geometric and vegetal motifs (or confronted birds?), silk and silver-gilt thread, twelfth/ thirtheenth century, origin unknown (Trésor de la Cathédrale de Sens, no. B18).

PHOTOS: ANA CABRERA LAFUENTE

Compostela, and Toledo, as well as the extraordinary collection at Sens Cathedral in northern France (Figures 1.6a, b). ${ }^{21}$ Among their research concerns

Isábena Cathedral (Huesca, Aragon)," in Relics@ the Lab. An Analytical Approach to the Study of Relics, ed. M. Van Strydonck, J. Reyniers, and F. Van Cleven (Leuven: Peeters, 2018), 43-76; María Judith Feliciano, "El corpus epigráfico de los tejidos medievales en Iberia: nuevas aportaciones," in Arte y producción textil en el Mediterráneo medieval, ed. Laura Rodríguez Peinado and Francisco de Asís García García (Madrid: Polifemo, 2019), 289-318; Ana Cabrera Lafuente, "Following the Thread: Collecting Spanish Textiles at the Victoria and Albert Museum," in Collecting Spain: Spanish Decorative Arts in Britain and Spain, ed. Ana Cabrera Lafuente and Lesley E. Miller (Madrid: Polifemo, in press 2021).

21 The silk tapestry from Sens Cathedral illustrated in Figures 1.6a and 1.6b, which was reworked into a bag to hold relics at some point in its long history, has been generically assigned an Iberian or Sicilian origin; however, nothing can be stated definitively about its place of manufacture without further study. (See Eugene Chartraire, Les tissues anciens du trésor de la Cathedrale de Sens [Paris: Honoré Champion, 1911], 45-46, n.58). The research carried out by Ana Cabrera Lafuente and María Judith Feliciano at Sens Cathedral in October 2017 was made possible thanks to the assistance of Dorothée Censier and Virginie Garret of Musées CEREP, Ville de Sens, together with funding provided by their respective projects: for Cabrera Lafuente, the European Union's Horizon 2020 Research and Innovation Programme under the Marie Skłodowska-Curie Grant Agreement no. 703711, Interwoven; for Feliciano, the Max Van Berchem Foundation, Medieval Textiles in Iberia and the Mediterranean Research Project. 
are the uncertainties of an object's provenance, along with its multiplicity of use, reuse and manipulations, which are especially clear in the case of textiles. Following a separate strand, Laura Rodríguez Peinado will pursue an iconographic investigation of San Isidoro's later medieval textiles that bear Christian imagery, chief among them the magnificent fourteenth-century Pennant of San Isidoro. ${ }^{22}$ These embroidered works were not included in the first Treasury project, during which we carried out the initial dyes testing on several of the silk fragments at San Isidoro, thanks to funding from Rodríguez Peinado's own previous research project, the first major results of which were published in 2019. ${ }^{23}$

Two project members have been charged with addressing the movement of objects from Muslim to Christian lands from different points of view. Eduardo Manzano, a historian of Islam, is carrying out further investigation on Iberian objects in the Arabic sources. Manzano sees the pillaging of the caliphal palace of Madinnat al-Zahrā' around 1010 as a key moment at which treasured metalworks would have been dispersed across the Peninsula, some perhaps ending up in León (Figure 1.7) ${ }^{24} \mathrm{~A}$ distinct approach to the topic is taken by the art historian Mariam Rosser-Owen, whose research was crucial to the initial conception of the Treasury project. Her 2015 call to pay closer attention to "alternative modes of transfer between the cultures that inhabited the Iberian Peninsula" has gained deep and wide-spread traction; ${ }^{25}$ along this vein her work now mines the movements of materials, delving into the ivory and gold trade between north Africa and the Iberian peninsula especially during Âmirid rule

22 For prior bibliography on the Pennant, or Pendón, de San Isidoro, see Chpt. 2, n.85.

23 The project headed by Laura Rodríguez Peinado was Las manufacturas textiles andalusíes: caracterización y estudio interdisciplinar, HAR2014-54918-P; see the volume edited by Rodríguez Peinado and Francisco de Asís García García, Arte y producción textil en el Mediterráneo medieval (Madrid: Polifemo, 2019), especially Rodríguez Peinado, "El Mediterráneo y la internacionalización de la producción textil medieval," 17-5o (esp. 3241 for San Isidoro and the Cathedral of León); and Enrique Parra Crego, "Caracterización de materiales de tejidos medievales hispanos," 347-366. See also Rodríguez Peinado, "Los textiles como objetos de lujo y de intercambio," in Las artes en al-Andalus y Egipto: contextos e intercambios, ed. Susana Calvo Capilla (Madrid: Ergástula, 2017), 187-205.

24 His recent monograph sets the stage: Eduardo Manzano Moreno, La corte del Califa. Cuatro años en la Córdoba de los omeyas (Barcelona: Crítica, 2019). See also Manzano, "Entre faits et artefacts: interprétations historiques et données archéologiques en al-Andalus," in La culture materielle: un objet en question. Anthropologie, archéologie et histoire, ed. Luc Bourgeois, Danièle Alexandre-Bidon, Laurent Feller, Perrine Mane, Catherine Verna, and Mickaël Wilmart (Caen: Presses universitaire, 2018), 93-111.

25 Mariam Rosser-Owen, "Islamic Objects in Christian Contexts: Relic Translation and Modes of Transfer in Medieval Iberia," Art in Translation 7/1 (2015): 39-64, at 40. 


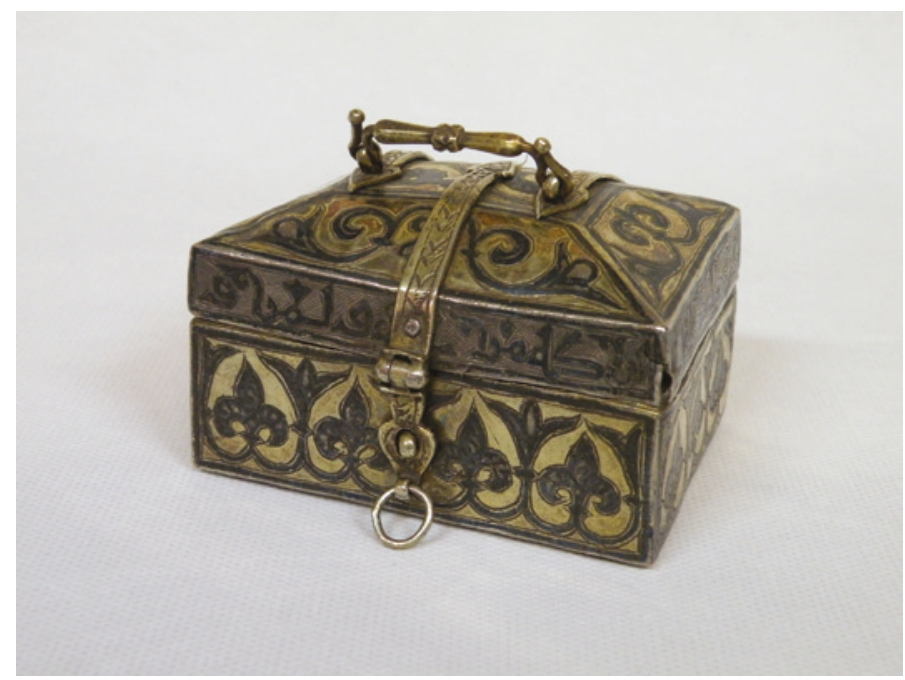

FIGURE 1.7 Andalusi casket, nielloed silver, eleventh century? (Museo de la Real Colegiata de San Isidoro de León, Inv. No. IIC-3-089-002-0015). PHOTO: THERESE MARTIN

in the decades around the turn of the eleventh century. ${ }^{26}$ Both Manzano and Rosser-Owen examine the larger Islamicate world within which luxury objects originated or were manufactured, together with the routes by which such items might have made their ways to treasuries in León and beyond.

Issues concerning the movements of objects also extend beyond works from Islamic lands. At San Isidoro, a delicate silver Fatimid box once shared space not only with several silver Andalusi caskets, ${ }^{27}$ but also with

26 Mariam Rosser-Owen, "Ivory in al-Andalus: Its Supply and Meaning in the Late 1oth Century," in Festschrift in Honour of Anthony Cutler, ed. Merih Danali Cantarella and Cali Buckley (Munich: Hirmer Verlag, in press 2021). See also Rosser-Owen's forthcoming monograph, Cultural Patronage and Political Legitimacy in al-Andalus, Handbook of Oriental Studies Series (Leiden: Brill, in press 2021). The larger context for trade in luxury goods across northern Africa is the subject of an important recent exhibition, Caravans of Gold, Fragments in Time: Art, Culture, and Exchange across Medieval Saharan Africa, ed. Kathleen Bickford Berzock (Princeton and Oxford: Princeton University Press, 2019). See also Sarah Guérin, "Ivory and the Ties that Bind," in Whose Middle Ages? Teachable Moments for an Ill-Used Past, ed. Andrew Albin, Mary C. Erler, Thomas O'Donnell, Nicholas L. Paul, and Nina Rowe (New York: Fordham University Press, 2019), 140-153.

27 See the new exhibition catalogue on Andalusi metalwork, Las artes delmetalen al-Andalus, ed. Sergio Vidal Álvarez (Madrid: Ministerio de Cultura y Deporte, 2019). A wealth of relevant research can be found in The Pisa Griffin and the Mari-Cha Lion. Metalwork, Art, and Technology in the Medieval Islamicate Mediterranean, ed. Anna Contadini (Pisa: Pacini Editore, 2018), especially Rafael Azuar, "Arqueología de la metalistería islámica de 


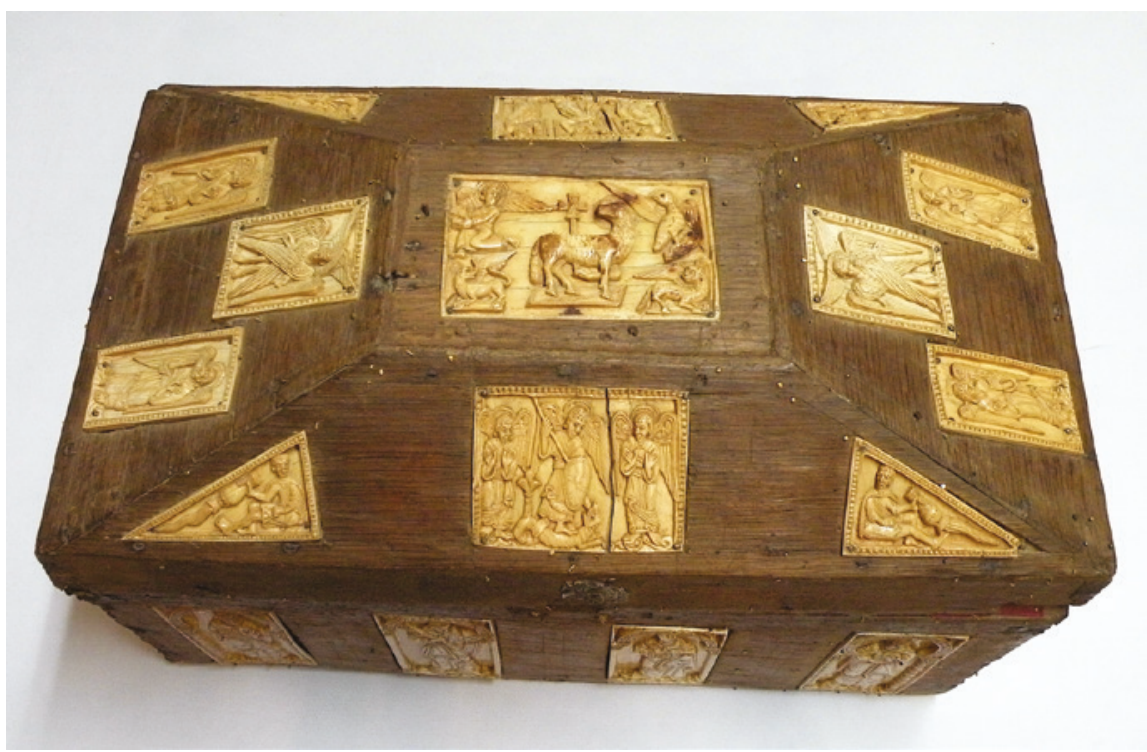

FIGU RE 1.8 Reliquary casket of Saints John the Baptist and Pelayo, ivory and wood, late eleventh century (Museo de la Real Colegiata de San Isidoro de León, Inv. No. IIC-3-089-002-OO23). See also Figs. 4.12a, 4.12b, 5.6, 5.9, 6.7a, 6.7b. PHOTO: THERESE MARTIN

a diminutive Viking container made of antler, ${ }^{28}$ a reliquary covered in colorful enamels that are typical of the Limoges style, and a set of three Sicilian painted ivory pyxides, along with other geographically distinct works including a multitude of figural ivories produced in León itself (Figure 1.8). ${ }^{29}$

al-Andalus durante los reinos de Taifa (Siglo V HG/XI DC)," 281-292, and Julian Raby, "The Inscriptions on the Pisa Griffin and the Mari-Cha Lion: From Banal Blessings to Indices of Origin," 305-36o + addendum to n.73. See also Susana Calvo Capilla, "Las artes en alAndalus y Egipto. Una red de intercambios permanente," in Las artes en al-Andalus y Egipto: contextos e intercambios, ed. Susana Calvo Capilla (Madrid: Ergástula, 2017), 9-22. In a January 2020 paper given jointly with Corinne Mühlemann, Beate Fricke questioned the Fatimid origin of the silver casket at San Isidoro: "Niello and Lampas: The Transfer of Craft Knowledge between Baghdad, al-Andalus and Northern Europe," presented at Dialogues in the Late Medieval Mediterranean: Methodological Encounters and (Dis) Encounters, International Workshop of the Casa Árabe de Madrid, organized by María Marcos Cobaleda, Borja Franco Llopis, and Antonio Urquízar Herrera.

28 Fruitful discussions with Nancy Wicker led initially to scholarly collaboration on this tiny object and then to the publication of her article, "The Scandinavian Container at San Isidoro," republished as Chpt. 9 in the present volume. For other Nordic-Iberian connections in this period, see Kurt Villads Jensen, Crusading at the Edges of Europe: Denmark and Portugal c.100o-c.125o (Abingdon and New York: Routledge, 2016).

29 For the objects from San Isidoro in this list, see in the present chapter Figures 1.1, 1.2, 1.5ab, 1.7, and 1.8; others are illustrated in Chpt. 2. 


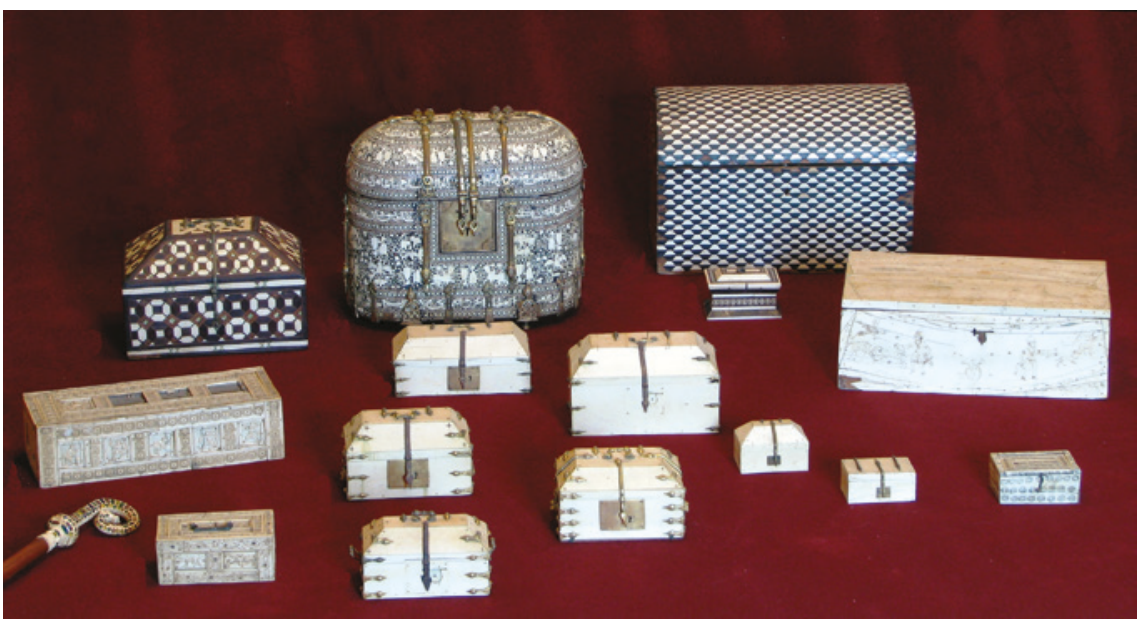

FIGURE 1.9 Ivory caskets and crozier in the Treasury of the Cappella Palatina, Palermo, late eleventh to thirteenth centuries; large and small inlaid caskets (back right) generally dated fourteenth to fifteenth centuries (the treasury pertains to the Fondo Edifici di Culto of the Ministero dell'Interno).

PHOTO: SILVIA ARMANDO

Such a multifarious collection obliges a definitive conceptual shift, recognizing the geographic resonance of objects for medieval collectors and beholders. Standing out among these distinctive works is the ivory manufacture traditionally attributed to Sicily and southern Italy, as revealed by Silvia Armando's in-depth investigations. ${ }^{30}$ Her groundbreaking research brings San Isidoro into comparison with the Norman treasury at Palermo, which boasts a collection of medieval ivories even greater than the Leonese holdings (Figure 1.9). In the coming years, her work will also reconsider the presence of painted "Siculo-Arabic" ivories in ecclesiastical treasuries across the Iberian Peninsula, interrogating especially their distribution along pilgrimage routes.

At San Isidoro, the elite viewers of these precious and exotic containers must have appreciated the prestige inherent in the rich materials as well as in

30 Silvia Armando, "L'Avorio di elefante nel Mediterraneo Medievale: Circolazione, disponibilità, usi (X-XIII secolo)," in Sharing Material Culture: Ivory and Bone Artefacts from the Mediterranean to the Caspian Sea, From Antiquity to the Middle Ages, ed. Michelina Di Cesare, special issue, Quaderni di Vicino Oriente 15 (2019): 215-278. A recent study of the ivories at Salerno offers a useful model of interdisciplinary investigation for research on collections like that of San Isidoro: The Salerno Ivories: Objects, Histories, Contexts, ed. Francesca Dell'Acqua, Anthony Cutler, Herbert L. Kessler, Avinoam Shalem, and Gerhard Wolf (Berlin: Gebr. Mann Verlag, 2016), especially the chapter by Sarah M. Guérin, "The Tusk: Origins of the Raw Material for the Salerno Ivories," 21-30. 
the objects' origins in faraway places. ${ }^{31}$ This fruitful tack will be pursued further by Jitske Jasperse, who traces the material culture networks of moving women and their portable objects, including a Portuguese royal daughter who married into the Flemish nobility. ${ }^{32}$ What might Teresa (1151-1218) — called Matilda in her new home-have brought with her from the Iberian Peninsula that contributed to the shaping of her life and of courtly culture during her long tenure as a Flemish countess? By piecing together the material traces connected to individuals like Teresa, we can gain a more complete understanding of their intimate connections with artifacts, shedding light on the lived experiences of both women and men. Jasperse's art historical investigations are complemented by the historical analyses of Christian Raffensperger, whose research on dynastic marriages, political connections, family networks, and the historiography of Eastern Europe will be brought to bear especially on the documentary sources. ${ }^{33}$ As the recent monographs by both Raffensperger and Jasperse have shown, in marriage, elite women themselves embodied exchange, and they publicly enacted alliances by moving from their home lands to new places. ${ }^{34}$ There they were assimilated into their husbands' lines while bringing along traditions of their own as well as precious objects. ${ }^{35}$ Through their marriages, elite women became the key contact points in political-cultural networks; as

31 For the evocation of distant geographies through the medium of splendid silks, see the studies in Juliane von Fircks and Regula Schorta, eds., Oriental Silks in MedievalEurope (Riggisberg: Abegg-Stiftung, 2016). With the publication of volumes like this one, the Abegg-Stiftung in Riggisberg, Switzerland has been fomenting exemplary scholarship on the collection, conservation, and exhibition of textiles, including its own magnificent medieval holdings.

32 Jitske Jasperse, "Of Seals and Siblings: Teresa/Matilda (d. 1218), Queen of Portugal and Countess of Flanders," Journal of Medieval Iberian Studies 12/3 (2020), open access: https://doi.org/10.1080/17546559.2020.1805120.

33 See the volume of studies currently being prepared by Christian Raffensperger, ed., Authorship, Worldview, and Identity in Medieval Europe (Abingdon and New York: Routledge, forthcoming 2021), including a chapter by Jitske Jasperse, "Treasuries as Windows to the Medieval World: San Isidoro de León and Saint Blaise at Braunschweig."

34 Christian Raffensperger, Ties of Kinship: Genealogy and Dynastic Marriage in Kyivan Rus' (Cambridge, MA: Harvard University Press, 2016); Jitske Jasperse, Medieval Women, Material Culture, and Power: Matilda Plantagenet and Her Sisters (Leeds: Arc Humanities Press, 2020), open access: http://library.oapen.org/handle/20.500.12657/37333.

35 On this matter, see the recent wide-ranging studies in Tracy Chapman Hamilton and Mariah Proctor-Tiffany, eds., Moving Women, Moving Objects, 300-1500 (Leiden: Brill, 2019). See also the monographs published separately by each of the editors: Tracy Chapman Hamilton, Pleasure and Politics at the Court of France: The Artistic Patronage of Queen Marie of Brabant (1260-1321) (Turnout: Brepols, 2019); Mariah Proctor-Tiffany, Medieval Art in Motion: The Inventory and Gift Giving of Queen Clémence of Hongrie (University Park, PA: The Pennsylvania State University Press, 2019). 
such, the pivotal importance of these alliances in the history of the Middle Ages must not be underestimated. ${ }^{36}$

Beyond surviving treasures and the written sources that make reference to artifacts and their owners, the present Treasury project opens new lines of research by investigating the imaging of luxury objects in manuscripts and frescos. These textual and visual re-creations brought to a much wider public the elite objects that would otherwise be restricted to the most exclusive of audiences. But what exactly was selected for detailed representation, and how do surviving pieces compare to their painted avatars? Such questions are being addressed by three art historians: Julie Harris, Shannon Wearing, and Jordi Camps. Harris will dig further into issues related to the Jewish presence in León-Castilla, tackling for the Treasury project certain "lost treasures" of Castile's Jews from the standpoint of art history and historiography. What is the evidence that storied objects such as the Hilleli Codex (copied in León ca. 1000) actually existed? And what of the engraved goblet said to be presented to King Alfonso X (r. 1252-1284) by the poet Todros Halevi Abulafia? The power in these objects and their hold as memory, invented or not, form part of Harris's current investigation. She is also addressing the Hebrew illuminated Bible in Iberia as an entity that should be situated on a continuum of Jewish thought, extending from rationalists like Maimonides (1138-1204), who wrote before any surviving example, to mystically inclined thinkers like Profiat Duran (ca. 1350-ca. 1415), who was active near the end of their production. It is this end stage that links in with the Treasury project, for the Bible was by then seen as possessing a power that was artifactual, almost talismanic, as indicated by the Hebrew word Segulah that can mean both treasure and remedy. ${ }^{37}$ Works such as these were held up for remembrance through written narratives, while the objects under investigation by Wearing and Camps were visually recorded, or indeed invented. Wearing centers especially on manuscripts that make use of brilliant gold leaf - the very definition of "illuminated" - to highlight the luxurious metallic nature of carefully selected objects on the page. She interrogates the simulation of metallic preciousness on parchment as a way

36 See the useful corrective offered by Katherine Weikert, "The Princesses Who Might Have Been Hostages: The Custody and Marriages of Margaret and Isabella of Scotland, 12091220s," in Medieval Hostageship c. 700-c. 1500: Hostage, Captive, Prisoner of War, Guarantee, Peacemaker, ed. Matthew Bennett and Katherine Weikert (Abingdon and New York: Routledge, 2019), 122-139.

37 In a parallel topic of research, Julie Harris's 2020 fellowship at the Clark Institute centered on the tension between ornament and meaning in the decorative carpet pages of Iberian Hebrew Bibles, especially their materiality and function. 
to understand the deliberate tension between the pictorial and the material during the central Middle Ages. ${ }^{38}$ Camps is continuing his investigations of the choices behind the depiction of treasured metalworks on altar frontals and in large-scale paintings on the walls of Romanesque churches, while also tackling the vexed issue of their display in modern museums. ${ }^{39}$ The research lines of Harris, Wearing, and Camps bring to the current Treasury project fresh and interrelated ways of thinking about objects, whether legendary or real, in order to discern the inspirations behind their visual representations. Camps's work takes us up to the modern day, as does the research of Amanda Dotseth, who focuses on how collected treasures, then and now, tell stories that change according to the backdrop against which they are viewed. ${ }^{40}$ Dotseth's emphasis on questions of ownership, collecting, and display puts the spotlight squarely on the shifting meanings and museographies of medieval works of art. ${ }^{41}$

The initial Treasury project demonstrated that collaboration among international scholars with a range of interdisciplinary methods and approachestextual, visual, material, and technical — successfully opens new windows onto the past. An essential characteristic running through both phases of the project is the consolidation of a multidisciplinary team-experts in medieval art, archaeology, and the histories of Islam, Judaism, and Christianity—from universities, research centers, and museums in Italy, Germany, Spain, Switzerland, the UK, and US, in order to undertake innovative research as a collective. Although

38 This line of thinking is laid out in Joseph Salvatore Ackley and Shannon L. Wearing, "Preciousness on Parchment: Metals, Materiality, and Pictoriality in Illuminated Manuscripts," in Illuminating Metalwork: Metal, Object, and Image in Medieval Manuscripts, ed. Joseph Salvatore Ackley and Shannon L. Wearing (Berlin: Walter de Gruyter, in press 2021).

39 Recent publications by Jordi Camps include "Pintura mural románica en el Museu Nacional d'Art de Catalunya: actualidad y retos de una colección singular," in Pintado en la pared: el muro como soporte visual en la Edad Media, ed. Santiago Manzarbeitia Valle, Matilde Azcárate Luxán, and Irene González Hernando (Madrid: Ediciones Complutense, 2019), 439-459; Jordi Camps, Manuel Castiñeiras, John McNeill, and Richard Plant, eds., Romanesque Patrons and Processes: Design and Instrumentality in the Art and Architecture of Romanesque Europe (Abingdon and New York: Routledge, 2018).

40 Amanda Dotseth, "Collecting San Isidoro de León: Art and National Narrative," in Collecting Spain: Spanish Decorative Arts in Britain and Spain, ed. Ana Cabrera Lafuente and Lesley E. Miller (Madrid: Polifemo, in press 2021).

41 Amanda Dotseth, ed., Collective Display: Medieval Objects Out of Isolation (Turnhout: Brepols, forthcoming 2021). On the matter of display, see also the admirable interactive exhibition, "Gegenstände des Transfers," especially for ways of understanding the movements of medieval ideas and objects across cultures, by Vera Beyer, Isabelle Dolezalek, and Sophia Vassilopoulou, eds., Objects in Transfer: A Transcultural Exhibition Trail through the Museum für Islamische Kunst in Berlin (Berlin: Staatliche Museen zu Berlin, 2017); http:// www.objects-in-transfer.sfb-episteme.de/\#/. 
multidisciplinarity and internationalization are rightly held up as research ideals by funding bodies, the practicalities of reaching such lofty goals are rarely given the same attention. To break through disciplinary barriers, it is necessary for scholars to work closely together, debating their ideas in order to weigh and appreciate the types of evidence brought to bear in other fields. For an international group to function as a true team, there must be repeated contact that facilitates discussion and allows scholars the necessary time first to learn from one another and then to apply the new knowledge to their own research.

Beyond reaching the larger community of scholars with the results of our research, the Treasury project aims to move further out into the consciousness of modern society, locating for an interested general public the Leonese collection within its broader historical framework and holding it up for comparison with other relevant sites. ${ }^{42}$ On a local level, by producing serious, groundbreaking scholarship that centers on San Isidoro de León, the Treasury project shines a new light on the extraordinary medieval objects held especially by the Museo de San Isidoro in León and the Museo Arqueológico Nacional in Madrid. We are especially gratified to be able to give back to San Isidoro, offering the painstaking fruits of our scholarly labors at this important juncture in the institution's history when it is restructuring and expanding the royal-monastic space to accommodate greater display of the medieval objects. Finally, on the societal front, it is increasingly clear that the stories we tell about the past continue to have real consequences in the present, whether limiting or liberating. By shifting the direction of our gaze so that the many collaborations across faiths and the repeated examples of protagonism by women during the central Middle Ages are brought into clear focus, scholarly investigation can act as a corrective to modern misperceptions about medieval religion and gender, contributing to a changed scope for attitudes and behavior in the present. ${ }^{43}$

42 To that end, various members of the Treasury project have given interviews to print, radio, and television media in León and Madrid; see for example Diario de León, 10 June 2019, https://www.diariodeleon.es/articulo/cultura/joyas-san-isidoro-conquista-europa/ 201906100400001898301.html.

43 Scholars like Karen Dempsey (National University of Ireland, Galway) offer an admirable model by engaging with virtual audiences on social media like Reddit—with its largely young male demographic - to answer questions about the archaeology of the Middle Ages, especially concerning the roles played by women in medieval castles: https://www. reddit.com/r/AskHistorians/comments/cb25bw/iama_archaeologist_who_specialises_ in_medieval/. For her scholarly publications, see recently Karen Dempsey, "Gender and Medieval Archaeology: Storming the Castle," Antiquity 93/369 (2019): 772-788, open access: https://doi.org/10.15184/aqy.2019.13; Karen Dempsey, Roberta Gilchrist, Jeremy Ashbee, Stefan Sagrott, and Samantha Stones, "Beyond the Martial Façade: Gender, Heritage and Medieval Castles," International Journal of Heritage Studies 26/4 (2020): 352369, open access: https://doi.org/10.108o/13527258.2019.1636119 
In sum, the medieval treasury at San Isidoro offers so much more to contemporary society than a static storehouse of luxury items retired from liturgical use and now displayed as a museum collection. This assemblage provides unexpected answers to a broad gamut of questions concerning the lives of medieval artifacts and people, with fruitful teamwork opening exciting new avenues for understanding the past as well as the present. In tracing its itineraries, both Treasury projects seek to tell a tale about the material and metaphorical qualities of historical artifacts, and in so doing to locate the cultures of Iberia within vibrant networks of far-flung connections. Our research sheds a bright light on the complicated provenance of medieval objects whose value was - and still is - enhanced once the disparate pieces are seen together. It is only through juxtaposition that the artworks' active voice can be heard, contributing to a dynamic conversation about belief systems, aspirational owners, gender roles, and changing power structures. In highlighting the paths far beyond Iberia that were taken by people and their objects in the shaping of San Isidoro's treasury, both research projects render visible medieval engagements with materiality in multiple ways. These included the acquisition of prized raw materials such as ivory or rock crystal, but also the cultivation of plants and animals from which fabrics and pigments were fashioned. The dialogue created by these artifacts speaks of the movements of component parts that bridged long distances across water and over land, after which the individual elements were integrated into precious items at various workshops before moving, again and again, until the objects and textiles finally came to rest in church treasuries. Transferred through routes of manufacture, commerce, war, diplomacy, and marriage, such artifacts were bought, stolen, repurposed, donated, and displayed at an owner's behest, acting as visible representations of status and ambitions, both in the medieval past and now. By visualizing the itineraries of artifacts from the central Middle Ages, we are reminded that the past was a time and place inhabited by real, interconnected women and men of differing social levels, religious affiliations, and global geographies, and that processes of the sort that led to the making of a treasury like San Isidoro's are still in full force today. 